\title{
Expression of biological activity of draculin, the anticoagulant factor from vampire bat saliva, is strictly dependent on the appropriate glycosylation of the native molecule
}

Citation for published version (APA):

Fernandez, A. Z., Tablante, A., Bartoli, F., Beguin, S., Hemker, H. C., \& Apitz-Castro, R. (1998).

Expression of biological activity of draculin, the anticoagulant factor from vampire bat saliva, is strictly dependent on the appropriate glycosylation of the native molecule. Biochimica et Biophysica Acta-general Subjects, 1425(2), 291-299. https://doi.org/10.1016/S0304-4165(98)00082-8

Document status and date:

Published: 23/10/1998

DOI:

10.1016/S0304-4165(98)00082-8

Document Version:

Publisher's PDF, also known as Version of record

\section{Please check the document version of this publication:}

- A submitted manuscript is the version of the article upon submission and before peer-review. There can be important differences between the submitted version and the official published version of record. People interested in the research are advised to contact the author for the final version of the publication, or visit the DOI to the publisher's website.

- The final author version and the galley proof are versions of the publication after peer review.

- The final published version features the final layout of the paper including the volume, issue and page numbers.

Link to publication

\footnotetext{
General rights rights.

- You may freely distribute the URL identifying the publication in the public portal. please follow below link for the End User Agreement:

www.umlib.nl/taverne-license

Take down policy

If you believe that this document breaches copyright please contact us at:

repository@maastrichtuniversity.nl

providing details and we will investigate your claim.
}

Copyright and moral rights for the publications made accessible in the public portal are retained by the authors and/or other copyright owners and it is a condition of accessing publications that users recognise and abide by the legal requirements associated with these

- Users may download and print one copy of any publication from the public portal for the purpose of private study or research.

- You may not further distribute the material or use it for any profit-making activity or commercial gain

If the publication is distributed under the terms of Article $25 \mathrm{fa}$ of the Dutch Copyright Act, indicated by the "Taverne" license above, 


\title{
Expression of biological activity of draculin, the anticoagulant factor from vampire bat saliva, is strictly dependent on the appropriate glycosylation of the native molecule
}

\author{
Ana Z. Fernandez a, Alfonso Tablante a , Fulvia Bartoli a, Suzette Beguin ${ }^{\mathrm{b}}$, \\ H.C. Hemker ${ }^{b}$, Rafael Apitz-Castro ${ }^{\mathrm{a}, *}$ \\ a Laboratorio de Trombosis Experimental, Centro de Biofísica y Bioquímica, I.V.I.C. Apartado 21827, Caracas 1020A, Venezuela \\ b Department of Biochemistry, University of Maastricht, Maastricht, The Netherlands
}

Received 13 May 1998; revised 1 July 1998; accepted 16 July 1998

\begin{abstract}
Draculin, a glycoprotein isolated from vampire bat (Desmodus rotundus) saliva, is a natural anticoagulant which inhibits activated coagulation factors IX (IXa) and X (Xa). The observation that under captivity conditions, the anticoagulant activity present in vampire bat saliva is dependent upon the salivation protocol, led us to investigate the possible relationship between the expression of biological activity of native draculin and the post-translational glycosylation of the protein backbone. Daily salivation of vampire bats yields a saliva that progressively decreases in anticoagulant activity, without any significant change in overall protein content, or in the amount of protein specifically recognized by a polyclonal anti-draculin antibody. Anticoagulant activity of the saliva is restored after a 4-day period of rest. Besides the marked difference in anticoagulant activity, purified native draculin, obtained from high- and low-activity saliva, shows significant differences in: (a) composition of the carbohydrate moiety, and (b) Glycosylation pattern. Furthermore, controlled chemical deglycosylation of native draculin, under conditions that do not affect the polypeptide backbone, progressively leads to complete loss of the biological activity. Our present results implicate that correct glycosylation of draculin is a seminal event for the expression of the biological activity of this glycoprotein. (c) 1998 Elsevier Science B.V. All rights reserved.
\end{abstract}

Keywords: Draculin; Glycosylation; Natural glycoform; Anticoagulant

Abbreviations: FIXa, activated factor IX; FXa, activated factor X; TFA, trifluoroacetic acid; TFMS, trifluoromethanesulfonic acid; FACE, fluorophore-assisted carbohydrate electrophoresis; SDS-PAGE, sodium dodecyl sulfate-polyacrylamide gel electrophoresis; ELISA, enzyme-linked immunosorbent assay; TMS, trimethylsilyl; GC-MS, gas chromatography-mass spectrometry analysis; 2-AB, 2-aminobenzamide; GalNAc, $N$-acetylgalactosamine; GlcNAc, $N$-acetylglucosamine; Man, mannose; Gal, galactose; AD, active draculin; ID, inactive draculin; PNA, peanut agglutinin; WGA, wheat germ agglutinin

* Corresponding author. Fax: +58-2-504-1093; E-mail: rapitz@ivic.ivic.ve

\section{Introduction}

Draculin, which is a selective inhibitor of the biological activity of activated coagulation factors IX (FIXa) and X (FXa), was first reported by ApitzCastro et al. as a glycoprotein of $88.5 \mathrm{kDa}$ obtained from saliva of vampire bat Desmodus rotundus [1]. This natural anticoagulant displays a microheterogeneous band pattern in SDS-PAGE, commonly found in most glycoproteins [2]. Since the initial isolation of draculin, it was observed that the anti-FXa biologi- 
cal activity of native draculin is not similar for all batches, even when saliva is obtained from the same animals. Among possible explanations to this fact one can invoke: (a) diminished production of the native protein, or (b) Impairment of relevant posttranslational modifications of the protein, both due to environmental changes that vampire bats undergo when kept in captivity.

It is now well established that the appropriate glycosylation of proteins may be relevant to the expression of their biological activity and that the set of glycoforms of a given polypeptide expressed by an organism is dependent on its physiological state [3,4]. In this paper, we report results that indicate that the anticoagulant activity of draculin is highly dependent on the proper glycosylation of the polypeptide backbone.

\section{Materials and methods}

\subsection{Materials and reagents}

Hydroxyapatite (Biogel-HTP), acrylamyde and silver staining reagents were purchased from Bio-Rad (Richmond, CA, USA). Coagulation factors were kindly provided by Dr. Rob Wagenvoord (Department of Biochemistry, University of Limburg, Netherlands). The activity of FXa was measured using the chromogenic substrates S2222 $\left(K_{\mathrm{m}}=200 \mu \mathrm{M}\right.$, Chromogenix, Sweden) and S2337 $\left(K_{\mathrm{m}}=200 \mu \mathrm{M}\right.$, Kabi Diagnostica, Sweden). For continuous measurement of thrombin generation we used the substrate SQ68. The following reagents were purchased from Oxford GlycoSystems (USA): GlycoFree deglycosylation kit, GlycoRelease kit, Signal 2-AB kit and HPLC GlycoSep. For the electrophoresis of the fluorophore-labeled carbohydrates we used the FACE $N$-linked oligosaccharide profiling system provided by Glyco (CA, USA). Neuraminidase $\mathrm{X}$ type (EC 3.2.1.18) was a gift from Dr. Raimundo Villegas (IDEA, Baruta, Venezuela). Freund's complete adjuvant (FCA) was from Calbiochem (CA, USA) and Freund's incomplete adjuvant (FIA) was from Gibco $(\mathrm{OH}$, USA). EGGstract purification system and Antichicken IgY AP conjugate were supplied by Promega (WI, USA). WGA and PNA lectins were provided by Vector (CA, USA). All other reagents used were of the highest quality commercially available. For graphics and mathematical approaches, Origin 5.0 Software was used (Microcal Software, MA, USA).

\subsection{Animals}

Vampire bats (Desmodus rotundus) were regularly captured from wild colonies in the region of Choroni (State of Aragua, Venezuela). The bats were kept in captivity, in individual, metabolic-type cages (Acme Metal Products, Chicago, IL, USA), under controlled light and temperature $\left(25^{\circ} \mathrm{C}\right)$. The animals were maintained on bovine blood anticoagulated with $3.8 \%$ sodium citrate at a ratio of 1:9. Food was given every $24 \mathrm{~h}$ and water was given ad libitum [5].

\subsection{Saliva collection}

For saliva collection, animals were anaesthetized with a mixture of 2.5\% 2-bromo-2-chloro, 1,1,1-trifluorethane (Halothan, Hoechst) and 30\% nitrous oxide in oxygen $[5,6]$. Once anesthetized, $20 \mu \mathrm{l}$ of $1 \%$ pilocarpine (Isopto Carpin, Alcon, Ft. Worth, TX, USA) was placed in the mouth in order to stimulate salivation. Saliva was collected in 2-ml microcentrifuge tubes and stored at $-20^{\circ} \mathrm{C}$ until use. Each sample was assayed for protein concentration and FXa inhibitory activity, and similar batches were kept separate and eventually pooled for draculin purification.

\subsection{Draculin purification}

Draculin was purified with a modification of the original method [1]. Briefly, the saliva was thawed and dialyzed for $14 \mathrm{~h}$ against distilled water at $4^{\circ} \mathrm{C}$. The dialysate, $1 / 3$ diluted, was adjusted to $1 \mathrm{mM}$ $\mathrm{NaCl}$ and loaded onto a hydroxyapatite column equilibrated with $\mathrm{NaCl}$ at a flow rate of $0.3 \mathrm{ml} /$ min. The column was washed with 5 column volumes of $1 \mathrm{mM} \mathrm{NaCl}$ ( $\mathrm{pH}$ 6.8), followed by 4 column volumes of $200 \mathrm{mM}$ potassium phosphate buffer $(\mathrm{pH}$ 6.8). After column washing, the elution was initiated using a phosphate buffer gradient from $200 \mathrm{mM}$ ( $\mathrm{pH}$

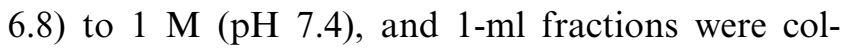
lected at a flow rate of $0.3 \mathrm{ml} / \mathrm{min}$. Anti-FXa activity of each fraction was assayed using a microplate 
adaptation of the FXa assay [1]. Fractions with the best anti-Xa activity were pooled and adjusted to $20 \%$ glycerol. An aliquot was taken for protein determination and SDS-PAGE, and the remainder were aliquoted and kept frozen at $-20^{\circ} \mathrm{C}$ until use. Presence of draculin with very low inhibitory activity was established by an ELISA method using a polyclonal anti-draculin antibody obtained from egg yolks.

\subsection{Factor Xa activity}

Factor Xa activity was assayed on specific chromogenic substrates. For the microplate assay of the FXa activity, $50 \mu \mathrm{l}$ of each of the hydroxyapatite column-eluted fractions was placed in a well with $100 \mu \mathrm{l}$ of buffer A $(0.05 \mathrm{M}$ Tris- $\mathrm{HCl}, 0.1 \mathrm{M} \mathrm{NaCl}$ (pH 7.35), with $0.05 \%$ egg albumin), $3 \mathrm{nM} F X a$ and $20 \mu \mathrm{l}$ of $4 \mathrm{mM} \mathrm{S}-2222$, in a final volume of $180 \mu \mathrm{l}$. After $15 \mathrm{~min}$ incubation at $37^{\circ} \mathrm{C}$ the optical density at $405 \mathrm{~nm}$ was recorded in a microplate reader (EL312e Bio-Kinetics reader microplate, Bio-Tek Instruments). The continuous assay of FXa activity was used for quantifying the anti-Xa activity of draculin. Briefly, 10-13 nmol of FXa was incubated with draculin for $1 \mathrm{~min}$ at $37^{\circ} \mathrm{C}$ in a cuvette containing buffer A. The cuvette was placed in a home-made fixed dual-wavelength photometer (Biochemistry and Instrumental Department, University of Limburg, Netherlands) for the continuous recording of the reaction at $405 \mathrm{~nm}$. The reaction was started with addition of $35 \mu \mathrm{l}$ of S-2337 (Final concentration= $400 \mu \mathrm{M})$. The final volume of the reaction mix was $500 \mu 1$.

\subsection{Glycosyl composition analysis}

This analysis was carried out in the Complex Carbohydrate Research Center (Georgia, USA, NIH Grant no. 2-P41-RR05351-06). Draculin samples $(200 \mu \mathrm{g})$ were analyzed for monosaccharide composition by preparing the trimethylsilyl (TMS) derivatives of the methyl glycosides followed by gas chromatography and combined GC-MS analysis. TMS methyl glycosides were prepared from the sample by methanolysis in $3 \mathrm{M} \mathrm{HCl}$ in methanol, followed by $N$-acetylation with pyridine and acetic anhydride. These procedures were accomplished as previously described [7]. GC analysis of the TMS methyl glycosides was done on an HP 5890 GC using a Supelco DB1 fused silica capillary column. GC/MS analysis was performed using a Hewlett Packard 5890 GC coupled to a 59790 MSD.

\subsection{Treatment of draculin with neuraminidase}

In order to probe the effect of sialic acid remotion in the inhibitory activity of draculin, native draculin was treated with neuraminidase (EC 3.2.1.18), $0.1 \mathrm{U} / \mathrm{ml}$ final concentration at room temperature; aliquots were taken at the indicated times and assayed for its residual anti-FXa activity.

\subsection{Chemical deglycosylation of native draculin}

Draculin was deglycosylated by a chemical procedure [8]. Briefly, draculin $(100 \mu \mathrm{g})$ was extensively dialyzed against $0.1 \%$ trifluoroacetic acid (TFA) at $4^{\circ} \mathrm{C}$ and freeze-dried for $>48 \mathrm{~h}$. Draculin was mixed with $50 \mu \mathrm{l}$ trifluoromethanosulfonic acid (TFMS) and the mixture was placed in a freezer at $-20^{\circ} \mathrm{C}$ for 4-12 h. Excess of TFMS was neutralized using $60 \%$ pyridine and then $0.5 \%$ ammonium bicarbonate. The polypeptide backbone was recovered by centrifugation/ultrafiltration, subjected to SDS-PAGE and assayed for its inhibitory activity against FXa as described.

\section{9. $N$-Linked oligosaccharides profile of draculin ( $F A C E)$}

The $N$-linked oligosaccharides from active and inactive draculin were compared by fluorophore-assisted carbohydrate electrophoresis (FACE) [9], following the procedure recommended by the manufacturer (Glyco, CA, USA). Briefly, the oligosaccharides from draculin were released by peptide $N$-glycosidase F (EC 3.5.1.52) and the released oligosaccharides were then labeled with a fluorophore (8-aminonaftalen-1,3,6-trisulfonate) at the reducing termini by reductive amination. The fluorescent labeled oligosaccharides were separated by PAGE. Imaging of the gel was performed on a UV light box and then photographed for further analysis. The resulting banding pattern represents the $N$-linked oligosaccharide profile of the glycoprotein. 


\subsection{Chemical cleavage and isolation of $\mathrm{N}$ - and O-linked oligosaccharides from draculin}

The hydrazinolysis procedure [10] was used for the obtainment of intact $\mathrm{N}$ - and $\mathrm{O}$-linked oligosaccharides from draculin. Draculin (active and inactive) was exhaustively dialyzed against $0.1 \%$ TFA and then dried thoroughly by lyophilization. The dried sample was mixed with hydrazine and placed for $5 \mathrm{~h}$ at $95^{\circ} \mathrm{C}$ in a heating block. The reaction mixture was transferred to a column for chromatographic removal of unreacted hydrazine and peptide material from glycans. The $N$-acetyl groups cleaved during hydrazinolysis are re- $N$-acetylated using a solution of acetic anhydride and unreduced by the addition of $\mathrm{Cu}^{2+}$ ions. The glycans were finally recovered using a ion-exchange column. One portion of the $\mathrm{N}$ and $O$-released oligosaccharides was saved for assaying inhibitory activity both on FXa and on thrombin generation in human blood plasma, and the remaining was labeled with 2-aminobenzamide (2-AB) by reductive amination using Signal 2-AB Labeling Kit (Oxford GlycoSystem, USA).

\subsection{HPLC of labeled oligosaccharides from draculin}

2-AB-labeled oligosaccharides from active and inactive draculin were separated by HPLC using a DEAE anionic-exchange column (GlycoSep C) and a hydrophobic column (GlycoSep H), both columns from Oxford GlycoSystems. The detection was performed at $330 \mathrm{~nm}$.

\subsection{Other methods}

Protein determination was done by the Bradford method [11]. SDS-PAGE was done as described by Schagger and von Jagow [12]. Gels were stained with Coomassie blue or silver staining. The procedure for the obtention of polyclonal anti-draculin antibodies from egg yolk was as previously described [13]. Briefly, two hens were inoculated subcutaneously with $50 \mu \mathrm{g}$ of draculin (active and inactive) in FCA and booster injections ( $50 \mu \mathrm{g}$ of draculin in FIA) were applied at $7,21,30,60$ days and then at 2 months interval. The eggs were collected and stored at $4^{\circ} \mathrm{C}$. IgY was obtained using the Promega purification system; both IgY antibodies were equally able to recognize active and inactive draculin. For Western-blotting analysis, appropriate methods were used $[14,15]$. The effect of the intact oligosaccharides on thrombin generation in human blood plasma was assayed as described [16]. Briefly, $400 \mu \mathrm{l}$ of defibrinated plasma and $100 \mu \mathrm{l}$ of buffer A, to which oligosaccharides were added, were incubated with Actin-FS $\left(37^{\circ} \mathrm{C}, 3 \mathrm{~min}\right)$. The reaction was started by adding $40 \mu \mathrm{l}$ of $7.5 \mathrm{mM}$ chromogenic substrate SQ68 and $20 \mu \mathrm{l}$ of $0.5 \mathrm{M} \mathrm{CaCl}_{2}$, and the optical density at $405 \mathrm{~nm}$ was recorded. The effect of adding an excess of a mixture of inactive draculin and the isolated oligosaccharides was also measured in both the purified F Xa system and in plasma, as described before.

The effect of preincubation of draculin with wheat germ agglutinin (WGA) and peanut agglutinin (PNA) lectins on the anti-Xa activity was assayed as follows: draculin $(0.18 \mu \mathrm{g})$ and the respective lectin $(0.1 \mathrm{mg})$ were incubated for $10 \mathrm{~min}$ at $37^{\circ} \mathrm{C}$; the chromogenic substrate $\mathrm{S} 2337$ was added and the reaction was started with the addition of FXa $(0.8 \mathrm{nM})$. Recording of the FXa activity was as described above. Preincubation of these lectins with FXa did not have effect on the amydolytic activity of FXa.

\section{Results}

\subsection{Dependence of the anticoagulant activity on salivation frequency}

Fig. 1A shows the results of anti-Xa activity and protein concentration of saliva obtained from three groups of five animals daily salivated for 5 days and after a rest of 3 days. As shown in Fig. 1A, daily salivation of vampire bats results in production of saliva with decreasing anti-Xa activity, reaching values around $45 \%$ of day 1 after 5 days of daily salivation; however, overall protein concentration during the same period, does not change significantly. Although our present results were obtained after 5 days of continuous salivation, it should be noted that the same trend is observed after up to 8 days of daily salivation, when the anti-Xa activity decreased to about $30 \%$ of the original (two animals). Fig. 1A also shows the recovery of anti-Xa activity to the values of day 1 after a 3-day period of rest. Further- 
A

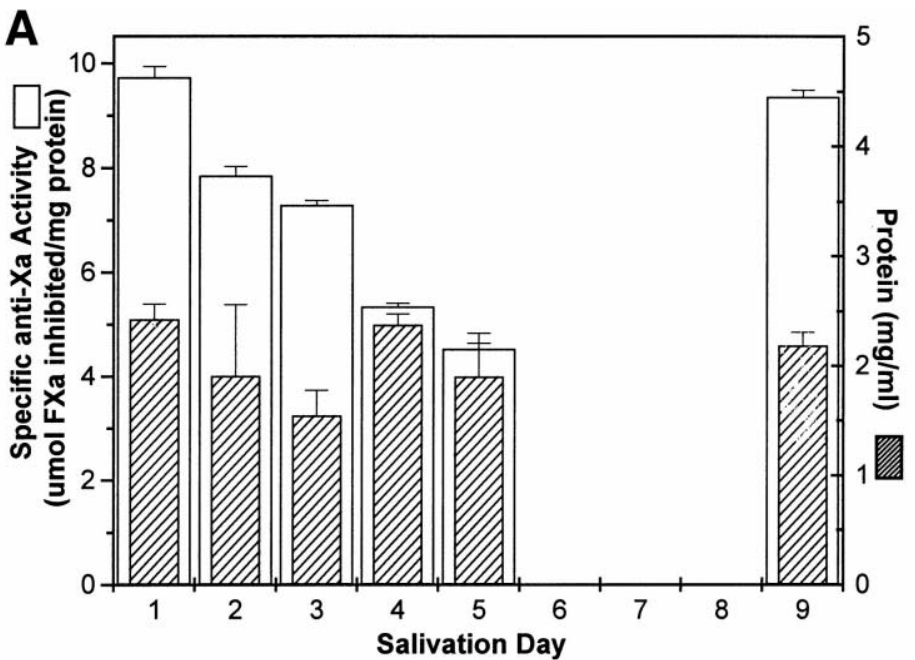

B

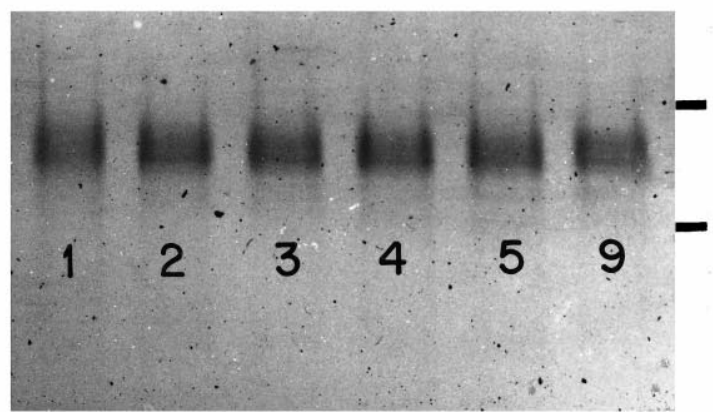

Fig. 1. (A) Specific anti-Xa activity (white columns) and protein concentration (dashed columns) of saliva obtained daily. Days 6, 7 and 8 correspond to salivation rest. Specific anti-FXa activity and protein concentration values are the mean \pm S.E. of saliva obtained from three groups of five animals each. (B) Typical Western blot pattern of salivas from days 1 to 5 and after rest period shown in A. Marks at right show the position of the $94 \mathrm{kDa}$ and $67 \mathrm{kDa}$ markers.

more (Fig. 1B), Western blotting analysis of the saliva, using a polyclonal anti-draculin antibody, shows that the amount of protein specifically recognized by the antibody is essentially identical from day 1 to day 5 , in contrast with the marked decrease in anticoagulant activity. Draculin, purified from separated pools of samples of 'high-' and 'low-activity' salivas, as previously described [1], was arbitrarily designed as 'active' or 'inactive' draculin. Active draculin (AD) inhibited FXa at molar ratios draculin:FXa below 4 , whereas inactive draculin (ID) needed molar ratios higher than 10 to achieve $>90 \%$ inhibition, under identical experimental conditions. Draculin with extremely low anticoagulant activity was detected by an ELISA procedure, as described in Section 2 .

\subsection{Glycosyl composition of active and inactive draculin}

Carbohydrate composition of $\mathrm{AD}$ and ID is shown in Table 1. The major monosaccharides identified in both proteins (sialic acid, GlcNAc, Man and Gal) indicate the presence of $N$-linked oligosacchar-

Table 1

Glycosyl composition of active and inactive draculin

\begin{tabular}{|c|c|c|c|c|}
\hline \multirow[t]{2}{*}{ Glycosyl residue } & \multicolumn{2}{|l|}{ Active draculin } & \multicolumn{2}{|l|}{ Inactive draculin } \\
\hline & $\begin{array}{l}\text { Percent of total } \\
\text { carbohydrate }\end{array}$ & $\begin{array}{l}\text { Percent }(\mathrm{w} / \mathrm{w}) \text { of total } \\
\text { protein }\end{array}$ & $\begin{array}{l}\text { Percent of total } \\
\text { carbohydrate }\end{array}$ & $\begin{array}{l}\text { Percent }(w / w) \text { of total } \\
\text { protein }\end{array}$ \\
\hline Sialic acid & 32.3 & 22.3 & 22.2 & 2.6 \\
\hline GlcNAc & 23.6 & 16.3 & 11.8 & 1.4 \\
\hline Mannose & 18.1 & 12.5 & 34.4 & 4.0 \\
\hline Galactose & 15.1 & 10.4 & 14.9 & 1.7 \\
\hline GalNAc & 5.8 & 4.0 & 4.5 & 0.5 \\
\hline Glucose & 3 & 2.1 & 8.6 & 1.0 \\
\hline Fucose & 0.8 & 0.6 & 3.6 & 0.4 \\
\hline Glucuronic acid & 0.8 & 0.6 & n.d. & n.d. \\
\hline Xylose & 0.7 & 0.5 & n.d. & n.d. \\
\hline
\end{tabular}

Carbohydrate/protein $(\% \mathrm{w} / \mathrm{w})$ : active draculin $69 \%$, inactive draculin $11.5 \%$. n.d., not detected. 


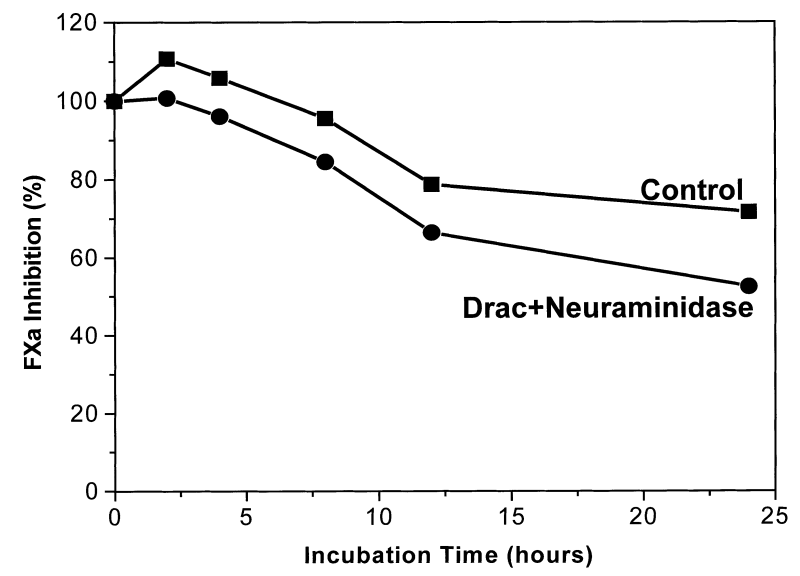

Fig. 2. Time course of anti-Xa activity of draculin treated with Neuraminidase. Native draculin incubated at $25^{\circ} \mathrm{C}$ with buffer A was used as control.

ides, although the presence of GalNAc suggests also the existence of $O$-linked oligosaccharides. Data in Table 1 show significant differences in carbohydrate composition between AD and ID, both quantitative and qualitative. While AD has about $69 \%(\mathrm{w} / \mathrm{w})$ carbohydrate content, in ID it only reached $11 \%$. Major qualitative differences are found in the relative amount of sialic acid, mannose, GlcNAc and glucose.

\subsection{Effect of neuraminidase treatment in anti-FXa activity of draculin}

Neuraminidase treatment of native, active draculin results only in $10 \%$ to $15 \%$ loss of anticoagulant activity, compared to the untreated sample, even after $24 \mathrm{~h}$ incubation (Fig. 2). The figure also shows that untreated draculin (control) progressively losses activity, reaching about $80 \%$ of the original after $24 \mathrm{~h}$ at $25^{\circ} \mathrm{C}$.

\subsection{Glycosyl profile analysis of active and inactive draculin}

The electrophoretic profile of enzymatically released oligosaccharides from AD and ID obtained by FACE is shown in Fig. 3. Internal standard consisting in a mixture of glucose polymers ranging from glucose 3 to glucose 11 was run simultaneously. As shown in the figure, marked differences are found in the oligosaccharide profiles of $\mathrm{AD}$ and ID. AD

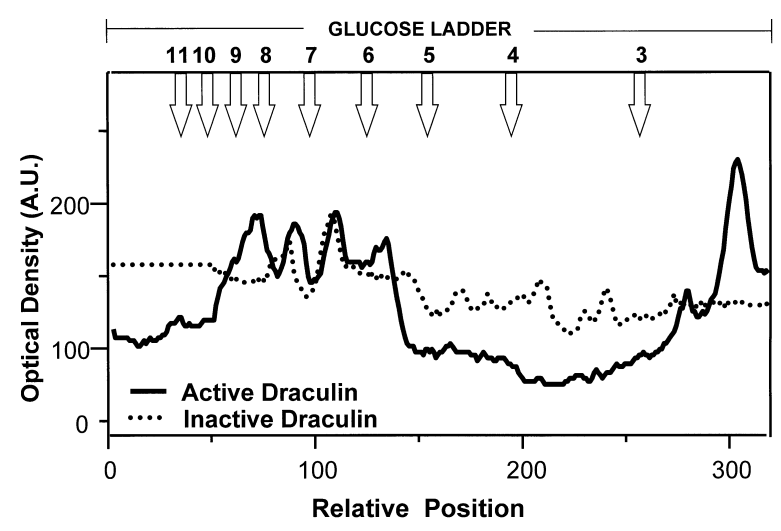

Fig. 3. FACE of enzymatically released $N$-oligosaccharides from active and inactive draculin. Arrows correspond to the position of the glucose ladder used as internal standard.

clearly displays a higher content of larger oligosaccharide chains than the inactive counterpart.

Additionally, chemically released oligosaccharides from $\mathrm{AD}$ and ID were chromophore-labeled and separated by HPLC. The anionic HPLC profile of chemically released oligosaccharides from $\mathrm{AD}$ and ID is shown in Fig. 4. Major differences in the elution pattern are observed in the area of neutral ( $\approx 5 \mathrm{~min}$ ) and monosialylated structures (10-15 $\mathrm{min}$ ), where peaks corresponding to inactive draculin are clearly more prominent. Di- and trisialylated structures are more abundant in active draculin, as can be seen from the peaks eluting at $20-25$ and at $45 \mathrm{~min}$, respectively. Differences can be observed also at higher elution times, where more complex structures appear. Hydrophobic-HPLC also shows marked differences in the elution pattern. They are especially important in the initial peaks, corresponding to charged structures, which are more prominent in active draculin (not shown).

\subsection{Effect of controlled chemical deglycosylation on draculin activity}

Active draculin, when subjected to chemical deglycosylation under conditions where the primary structure of the protein backbone is completely preserved as demonstrated by Sojar and Bahl [8], lose activity in a manner dependent on the degree of deglycosylation. Table 2 shows the effect of deglycosylation time of draculin on its inhibitory activity. The FXa inhibitory effect of draculin $(4.0 \mu \mathrm{g} / \mathrm{ml})$ decreased by 
Table 2

Effect of controlled chemical deglycosylation on anti-FXa activity by draculin

\begin{tabular}{lccc}
\hline Draculin $(\mu \mathrm{g} / \mathrm{ml})$ & \multicolumn{3}{c}{ Deglycosylation time } \\
\cline { 2 - 4 } & $0 \mathrm{~h}$ & $4 \mathrm{~h}$ & $12 \mathrm{~h}$ \\
\hline 2 & 39.1 & 28 & 0 \\
3.2 & 50 & 38.4 & 0 \\
4 & 93.8 & 57.3 & 0 \\
6.3 & $>95$ & n.d. & 0 \\
12.7 & $>95$ & n.d. & 11.2 \\
19.1 & $>95$ & $>95$ & 12.2 \\
\hline
\end{tabular}

n.d., Not determined.

$39 \%$ after $4 \mathrm{~h}$ deglycosylation, while it was completely lost after $12 \mathrm{~h}$ deglycosylation. The effect of deglycosylation on the mobility of draculin in SDSPAGE is seen in Fig. 5. The sharp band obtained after $12 \mathrm{~h}$ deglycosylation treatment corresponds to a polypeptide chain of about $72 \mathrm{kDa}$ molecular mass, and there is no difference between deglycosylated ID and AD (not shown). Furthermore, no lower molecular mass polypeptide was observed, indicating the integrity of the polypeptide chain. This is in good agreement with the molecular mass of the protein calculated from the amino acid composition of native draculin [1]. On the other hand, deglycosylated draculin is recognized by the polyclonal antidraculin antibody, showing that the polypeptide chain still conserves some identical immunologic epitopes.

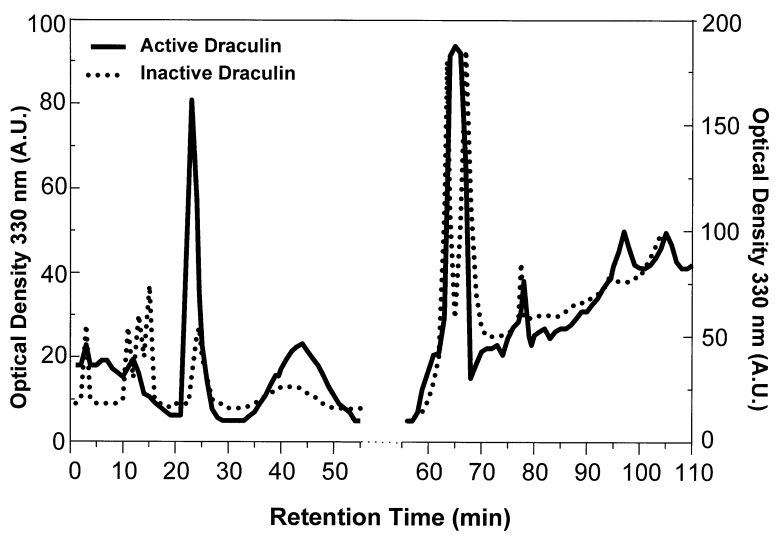

Fig. 4. DEAE-HPLC profile of labeled $N$ - and $O$-oligosaccharides from active and inactive draculin. Carbohydrate chains were released by hydrazinolysis and labeled with $2-\mathrm{AB}$ as described in Section 2.

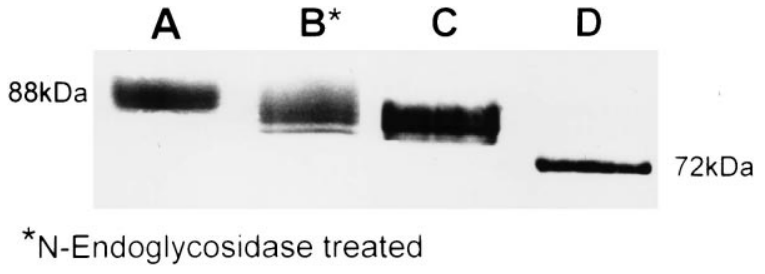

Fig. 5. SDS-PAGE of native and deglycosylated draculin. Approximate molecular masses are shown. Lane A, native draculin; lane B, $N$-endoglycosidase-treated draculin; lane C, chemically deglycosylated draculin $(4 \mathrm{~h})$; lane D, chemically deglycosylated draculin $(12 \mathrm{~h})$. Experimental conditions for $N$-endoglycosidase treatment (SDS 0.1\%, 2-mercaptoethanol $50 \mathrm{mM}$, Nonidet P-40 0.75\%) impairs assay of anti-Xa activity.

\subsection{Effect of released oligosaccharides from native draculin on Thrombin generation in whole human plasma}

Intact oligosaccharides obtained after hydrazinolysis of native $\mathrm{AD}$ were assayed for inhibitory activity on thrombin generation in human blood plasma, as described in Section 2. Even at concentrations far in excess of the concentrations of native draculin needed for complete inhibition of thrombin generation, addition of isolated oligosaccharides did not elicit any detectable change in the generation of thrombin. Also, adding intact oligosaccharides to inactive draculin did not restore its anti-F Xa activity (not shown). Similarly, incubation of plasma with the deglycosilated polypeptide backbone of draculin did not affect thrombin generation.

\subsection{Effect of lectins on the anti-Xa activity of draculin}

Fig. 6 shows the effect of WGA and PNA lectins on the anti-Xa activity of draculin. As can be seen, preincubation of draculin with WGA completely abolished the inhibitory activity of draculin on FXa, while PNA preincubation has a moderate effect on anti-FXa activity of draculin.

\section{Discussion}

The results reported above show that oligosaccharides linked to draculin are essential for the optimal expression of its biological activity against FXa. 


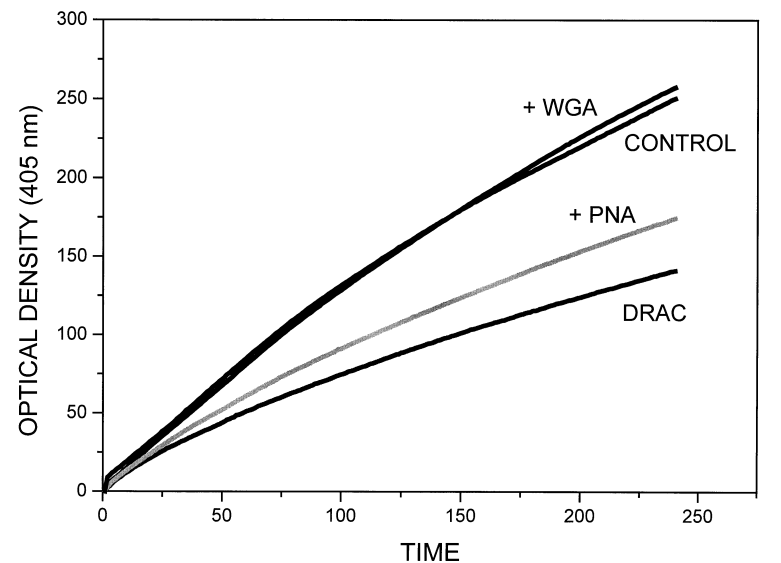

Fig. 6. Effect of incubation of native draculin with the lectins WGA and PNA on anti-FXa activity. The progressive curves of the activity of FXa on S2337 are shown. Control, FXa activity; DRAC, anti-FXa activity of draculin; +WGA, draculin preincubated with WGA; +PNA, draculin preincubated with PNA.

They also suggest that native draculin is secreted as a mixture of glycoforms, whose final anticoagulant activity depends upon the relative proportion of correctly glycosylated molecules to partially or improperly glycosylated ones. Hence, it seems that glycosylation and not protein synthesis is the limiting step for production of native draculin with optimal anticoagulant activity. Although it is possible that chemical deglycosilation, even under the mild conditions used, may cause protein denaturation, the fact that native draculin and chemically deglycosylated draculin are similarly recognized by the anti-draculin antibody suggest that chemical denaturation is not the main cause of the loss of the biological activity. At present, however, it is not clear if not only the amount of carbohydrates, but also the structure of the oligosaccharides plays a relevant role in the expression of the activity. Although it has been described that desialidation notably impairs the function of various glycoproteins [17,18], data in Fig. 2 suggest that sialic acid residues probably play a minor role in the biological activity of draculin. Evidence for the recognition of oligosaccharides linked to protein as significant part in the establishment of the biological activity of glycoprotein have increased in the last two decades. They have been implicated in a variety of functions such as structural role, in the conformation and stability of proteins, as target for immune response and microorganism attack, and in the mediation of cell-matrix and cell-cell interactions [19]. At the molecular level, it might be advantageous that the biological activity of draculin be dependent on the correctness of the carbohydrate moiety rather than in the protein backbone, in contrast with the case presented by Klaassen et al., who found that the acquisition of $N$-linked oligosaccharide moieties, and not their structures, was essential for biosynthesis of functional gastric $\mathrm{H}^{+}, \mathrm{K}^{+}$-ATPase in insect cells [20]. In this regard, the appropriate glycosylation of draculin may be in part responsible for the dual, independent, inhibitory action of native draculin on FIXa and FXa, suggesting a novel mechanism of inhibition which is different from other known natural inhibitors of FXa [21-23]. The inhibition of the anti-Xa activity of draculin, after incubation with the lectins WGA and PNA, gives further support to the role of the oligosaccharide chains in the expression of the anticoagulant activity. The fact that intact oligosaccharides, obtained from chemical cleavage of native draculin, do not inhibit FXa in artificial systems or in human plasma shows that these oligosaccharides, unlike the anticoagulant polysaccharide heparin, do not act by boosting the anticoagulant activity of a plasma serpin like antithrombin. Because the admixture of the isolated oligosaccharides from draculin to inactive draculin did not restore the inhibitory activity, it appears that, unlike in the heparinantithrombin interaction, covalent linkage is a prerequisite for biological activity. The ensemble of these results suggests that their role in the native protein may be related to the maintenance of a conformational state that recognizes and binds to certain specific domains in both Factor IXa and Xa. Since FXa has a key role in the coagulation system and its inhibition has been shown to be an important point for anticoagulant therapy, our present efforts have been focused to the study of anti-Xa activity of draculin; however, the fact that deglycosilated draculin did not affect thrombin generation in plasma suggest that inhibition of activated Factor IX is also dependent on draculin glycosylation.

The presence of different oligosaccharide structures in the same glycoprotein results in a subset of glycoforms that have different physical and biochemical properties which may influence the glycoprotein functionality [4]. A variety of reports shows that the extracellular environment, e.g., pregnancy and acute 
inflammation, may affect glycosylation of certain polypeptides [24]. Lifely et al. reported differences in the glycosylation pattern and the biological activity of CAMPATH-1H, a humanized IgG antibody used in the therapy of lymphoma, leukemia and rheumatoid arthritis, when it was expressed in different cell lines and grown under variable culture conditions [25]. The fact that draculin with poor inhibitory activity was obtained from batches of saliva after consecutive salivation days, which imposes a metabolic stress, in addition to the captivity conditions, implicates metabolic as well as environmental factors in the different glycosylation pattern observed in inactive draculin. Although there was no difference in the SDS-PAGE mobility between deglycosylated ID and AD, some minor, not easily detected polymorphism in the polypeptide sequence cannot be discarded, as shown in corticosteroid-binding globulin by Ali and Bassett [26]. At the moment, we do not have direct evidence of such polymorphism between ID and AD.

To summarize, draculin as a glycoprotein requires a particular glycosylation profile for expression of its maximal inhibitory activity, a fact that should be taken into consideration for further studies concerning cloning of the protein or the obtainment of glycopeptides biologically active against FXa, a potential strategy for the design of new anticoagulants.

\section{Acknowledgements}

The authors are deeply indebted to Dr. Magaly Bracamonte de Zambrano and Mr. Javier Campos (Rabies Division, Inst. Invest. Vet., FONAIAP, Maracay, State of Aragua, Venezuela) for their invaluable collaboration in the capture of wild vampire bats. This work was supported in part by the International Scientific Cooperation Program of the European Community-Andean Pact Countries, Contract CII*CT920062.

\section{References}

[1] R. Apitz-Castro, S. Beguin, A. Tablante, F. Bartoli, J.C. Holt, H.C. Hemker, Thromb. Haemostas. 73 (1995) 94-100.

[2] D. Garfin, Methods Enzymol. 182 (1990) 425-441.

[3] R.A. Dwek, C.J. Edge, D.J. Harvey, M.R. Wormald, R.B. Parekh, Annu. Rev. Biochem. 62 (1993) 65-100.

[4] T.W. Rademacher, R.B. Parekh, R.A. Dwek, Annu. Rev. Biochem. 57 (1988) 785-838.

[5] J.M. Dickson, D.G. Green, Lab. Anim. 4 (1970) 37-44.

[6] T. Cartwright, Blood 43 (1974) 318-326.

[7] R.K. Merkle, I. Poppe, Methods Enzymol. 230 (1994) 1-15.

[8] H.T. Sojar, O.P. Bahl, Methods Enzymol. 138 (1987) 341350.

[9] P. Jackson, Methods Enzymol. 230 (1994) 250-265.

[10] T. Patel, J. Bruce, A. Merry, C. Bigge, M. Wormald, A. Jaques, R. Parekh, Biochemistry 32 (1993) 679-693.

[11] M.M. Bradford, Anal. Biochem. 72 (1976) 248-254.

[12] H. Schagger, G. von Jagow, Anal. Biochem. 166 (1987) 368379.

[13] D. Burger, M.A. Ramus, M. Schapira, Thromb. Res. 40 (1985) 283-288.

[14] U.K. Laemmli, Nature 227 (1980) 680-685.

[15] H. Towbin, T. Staehelin, J. Gordon, Proc. Natl. Acad. Sci. U.S.A. 76 (1979) 4350-4354.

[16] H.C. Hemker, S. Wielders, H. Kessels, S. Béguin, Thromb. Haemostas. 70 (1993) 617-624.

[17] E. Recio-Pinto, W.B. Thornhill, D.S. Duch, S.R. Levinson, B.W. Urban, Neuron 8 (1990) 675-684.

[18] M. Salmi, S. Jalkanen, J. Exp. Med. 183 (1996) 569-579.

[19] A. Varki, Glycobiology 3 (1993) 97-130.

[20] C.H.W. Klaassen, J.A.M. Fransen, H.G.P. Swarts, J.J.H.H.M. De Pont, Biochem. J. 321 (1900) 419-424.

[21] C. Dunwiddie, N.A. Thornberry, H.G. Bull, M. Sardana, P.A. Friedman, J.W. Jacobs, E. Simpson, J. Biol. Chem. 264 (1989) 16694-16699.

[22] L. Waxman, D.E. Smith, K.E. Arcuri, G.P. Vlasuk, Science 248 (1990) 593-595.

[23] J.L. Seymour, R.N. Lindquist, M.S. Dennis, B. Moffat, D. Yansura, D. Reilly, M.E. Wessinger, R. Lazarus, Biochemistry 33 (1994) 3949-3958.

[24] C.F. Goochee, T. Monica, Biotechnology 8 (1990) 421-426.

[25] M.R. Lifely, C. Hale, S. Boyce, M.J. Keen, J. Phillips, Glycobiology 5 (1995) 813-822.

[26] S. Ali, J.R. Bassett, Steroids 60 (1995) 743-752. 